$$
\begin{aligned}
& \text { تاثير آلودَى صوتى بر ثروتئينهاى سرم خون رت نر نزاد ويستار } \\
& \text { آزاده حكمت'، زينب فهيمى' و سيد على حائرى روحانى }
\end{aligned}
$$

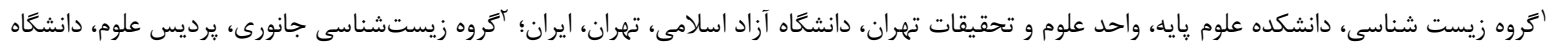

$$
\begin{aligned}
& \text { تهران، تهران، ايران } \\
& \text { hekmat@ut.ac.ir مسئول مكاتبات: آزاده حكمران، تمران، }
\end{aligned}
$$

ק جكيده. آلودگى صوتى يكى از عوامل خطرزا در محيط زيست است. يكى از منابع مههم اين آلودگى، صداى ناشى از حمل و نقل شهرى به ويزه سيستم راه آهن

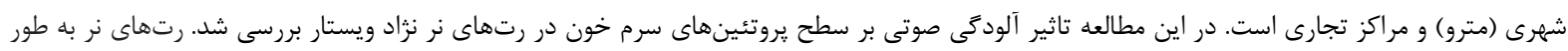

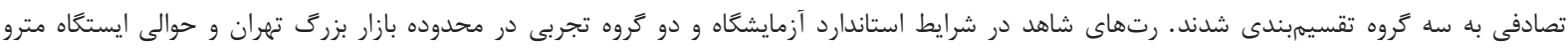

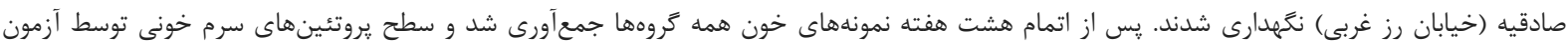

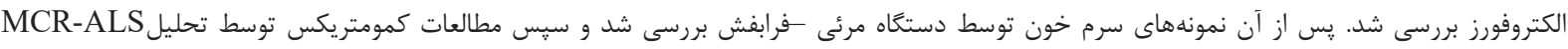

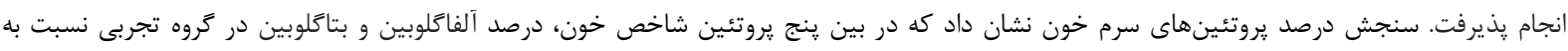

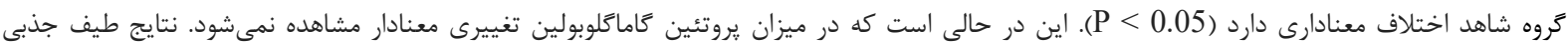

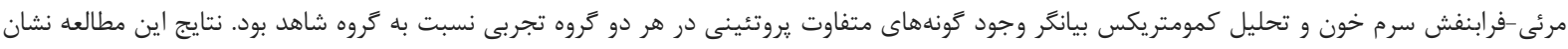

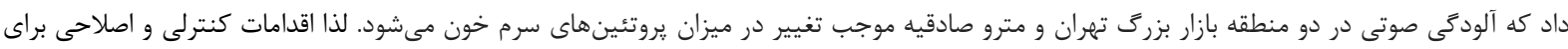

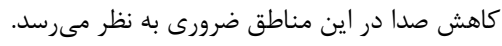

وازههاى كليدى. آلفاگلوبين، بتاكلوبين، تحليل كمومتريكس، طيف جذبى مرئى-فرابنفش، كاماگلوبولين

\title{
The effects of noise pollution on blood serum protein of Wistar male rats
}

\author{
Azadeh Hekmat ${ }^{1}$, Zeinab Fahimi ${ }^{1}$ \& Seyed Ali Haeri Rohani ${ }^{2}$ \\ ${ }^{1}$ Department of Biology, Science and Research Branch, Islamic Azad University, Tehran, Iran; ${ }^{2}$ Department of Animal \\ Biology, School of Biology, College of Science, University of Tehran, Tehran, Iran \\ Correspondent author: Azadeh Hekmat, hekmat@ut.ac.ir
}

\begin{abstract}
Noise pollution is one of the hazardous factors in the environment. One of the major sources of noise pollution is urban transportation, mostly the subway system and transportation in business centers. In this study, the effects of noise pollution on blood serum proteins level of Wistar male rats were investigated. Rats were divided into 3 groups ( 1 control and 2 experimental, $n=6)$. The control group was kept in standard conditions and the experimental groups were kept in Tehran Grand Bazaar and the vicinity of Sadeghiyeh metro-station (West Rose Street). After eight weeks, the blood serum proteins of each group were analyzed by electrophoresis assay. Then, the blood serum samples were investigated by Ultraviolet-Visible spectroscopy and chemometrics method (MCR-ALS). Assessment of serum proteins indicated that among 5 essential proteins in the blood, the percentage of alpha-globulins and beta-globulins displayed significant difference $(\mathrm{p}<0.05)$ in experimental groups. The UV-Visible spectra and chemometrics method showed that there were different species in both experimental groups as compared with the control group. Thus, the noise pollution of the areas studied led to alterations in blood proteins. Consequently, it seems crucial to take control and prevention measures for noise reduction in these areas.
\end{abstract}

Keywords. alpha-globulins, beta-globulins, gamma-globulins, chemometrics analysis, ultraviolet-visible spectra 
محيطهاى ير صدا مشاهده مىشوند، بنابراين كارگران و حتى مسافران در مترو در معرض ريسك مواجهه با صداى بيش از حدان حدان مدان

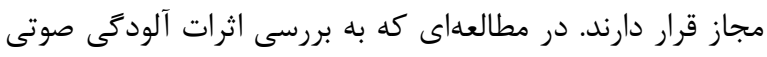

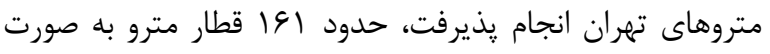

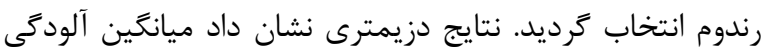

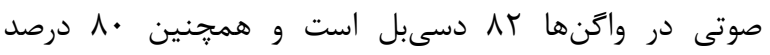

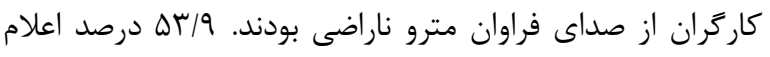

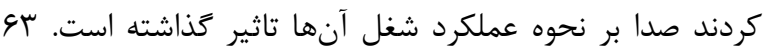

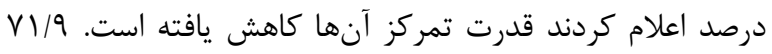

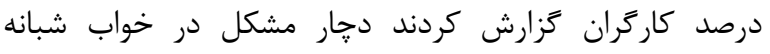

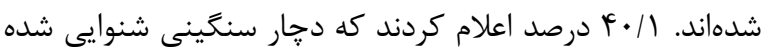

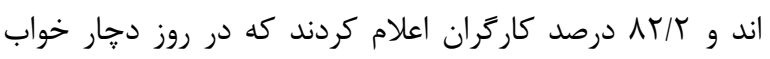

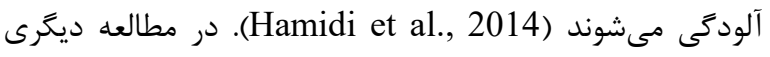

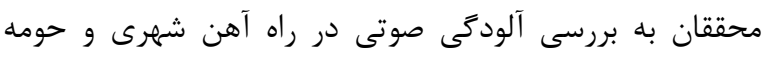

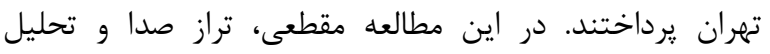

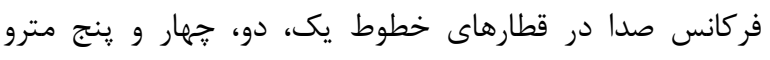

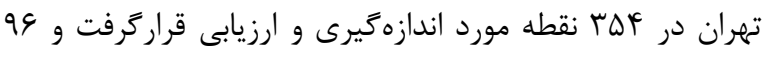

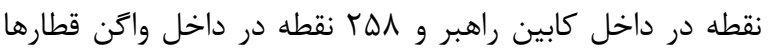

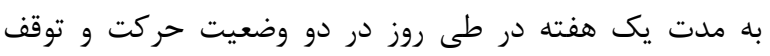

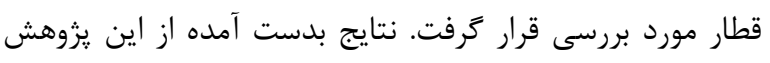

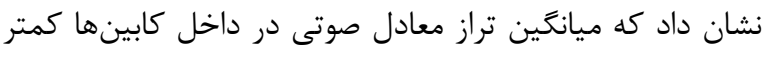

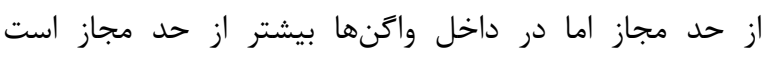

.(Hamidi et al., 2012) از ديكر سو در كلانشهرى همجون تهران وجود مراكز تجارى

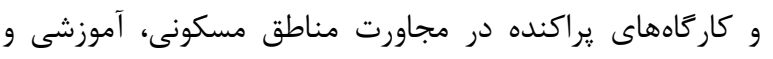

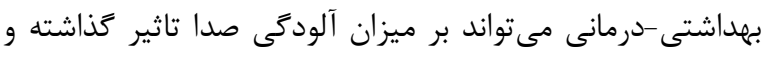

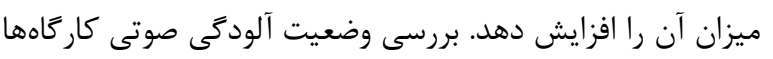

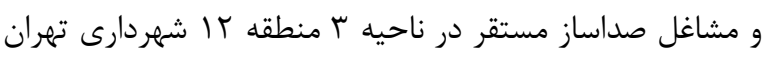

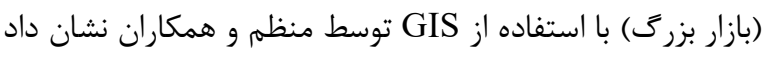

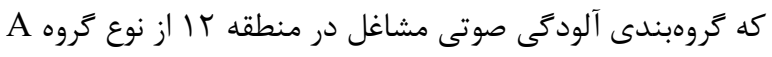

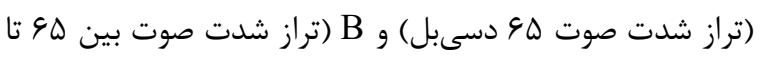

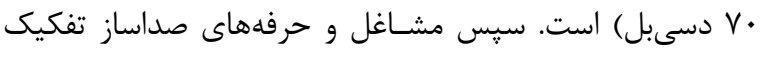

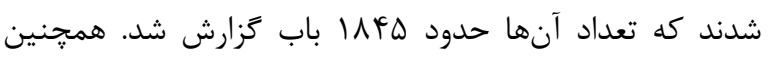

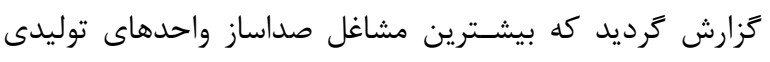

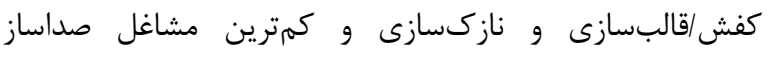
واحدهاى مسكرى هستند. به بيانى ديخر نتايج مطالعه انجام شده

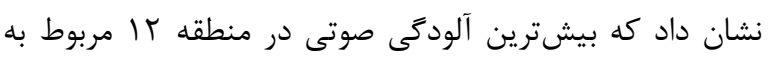

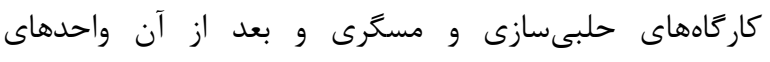
تراشكارى است كه در آلودگى صوتى منى منطقه بسيار اثركذار هستند (Hassani et al., 2017).
امروزه آلودكى صوتى يكى از مشكلات جوامع صنعتى است و مأح صداهاى مزاحم ناشى از محيط كار، ترافيك شهرى إنى و و وسايل

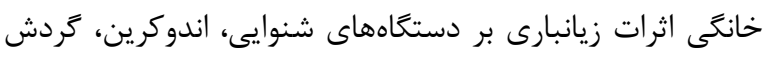

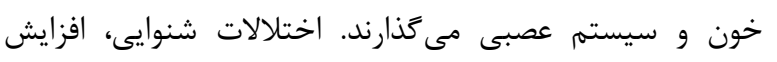

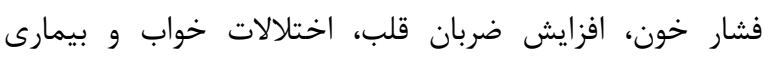

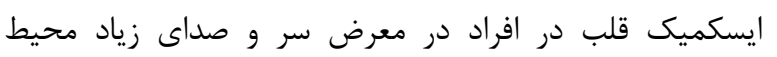

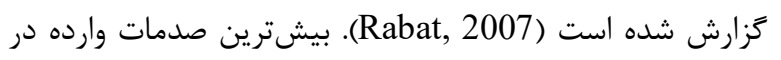

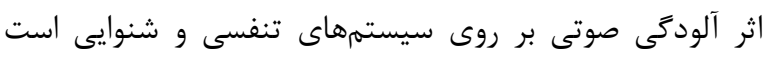

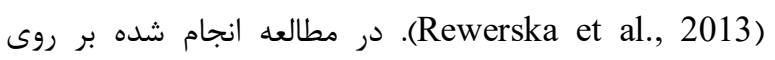

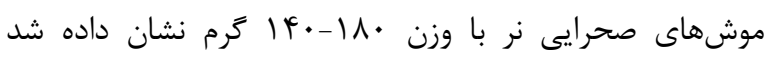

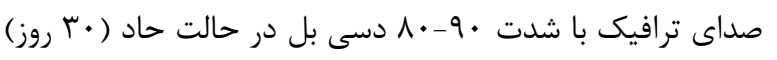

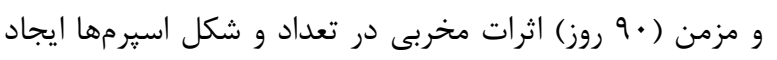

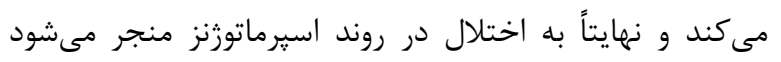
قramanik \& Biswas, 2012)

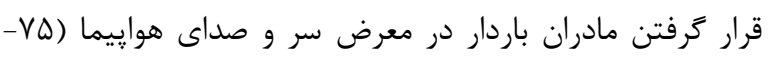

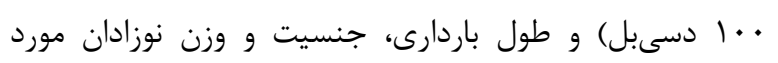

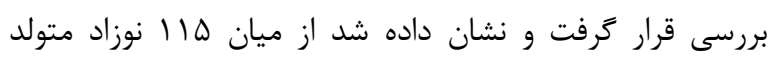

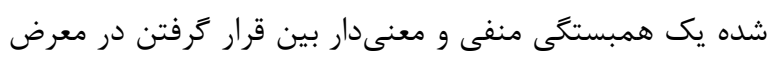

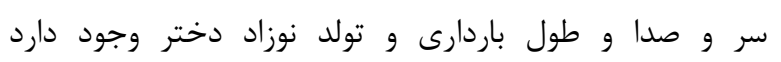

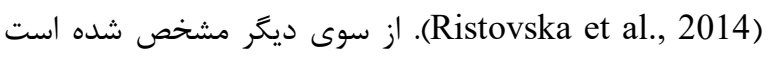

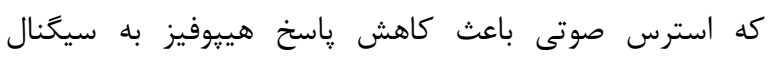

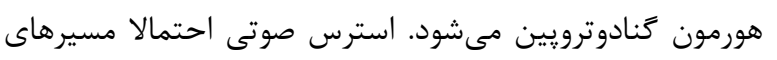

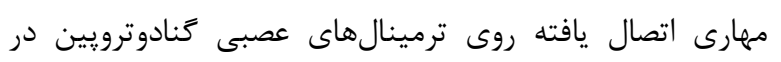

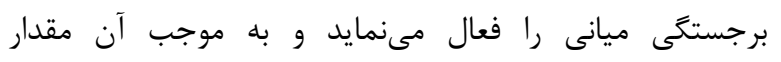

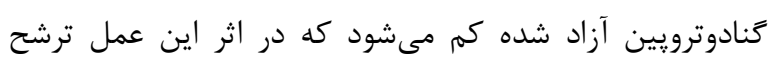
FSH, LH

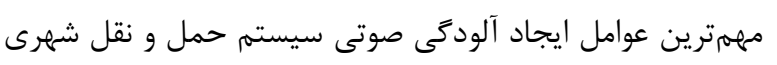

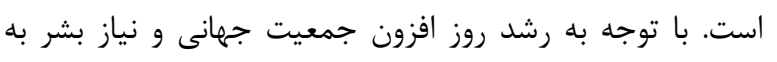

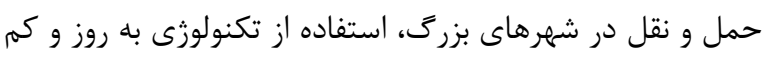

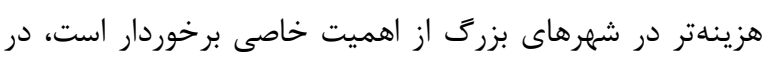

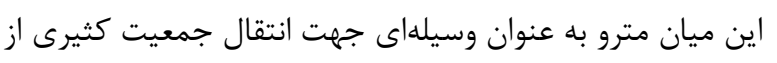

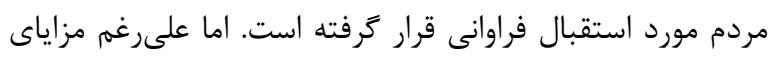

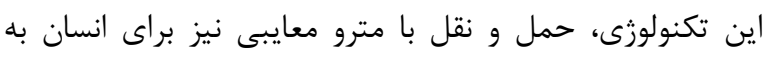

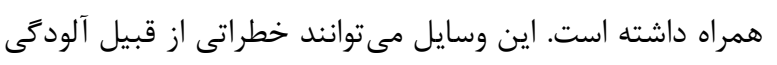

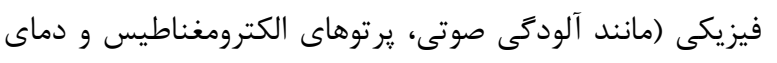

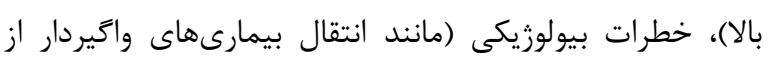

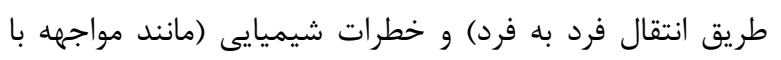

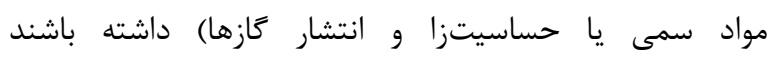
Gershon et al., 2005) 
ساختمان رز غربى بود (شكل (). بازار پارجه فروشان منطقه

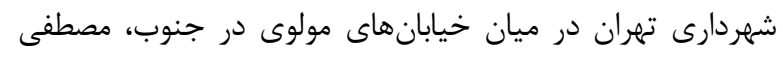

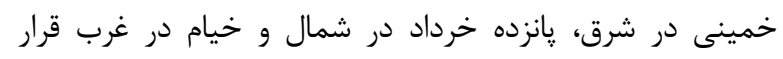

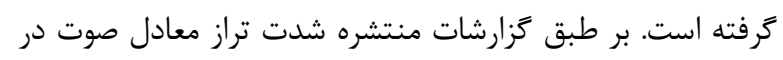

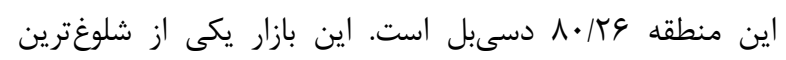

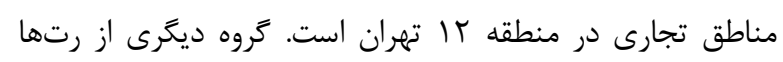

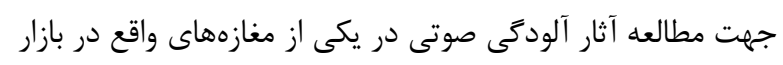

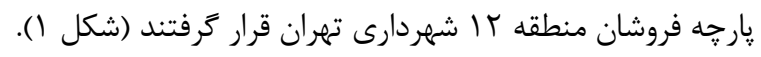
كروههاى آزمايشى في

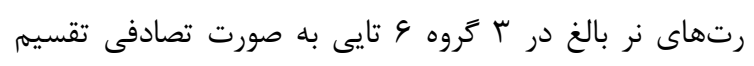

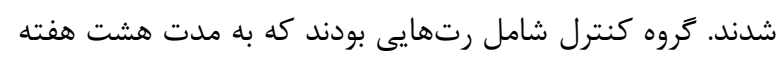

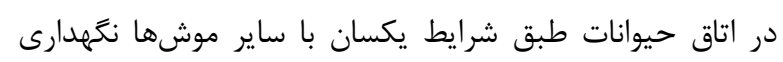

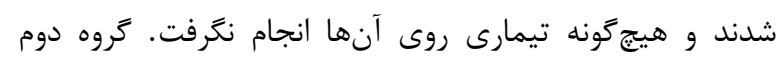

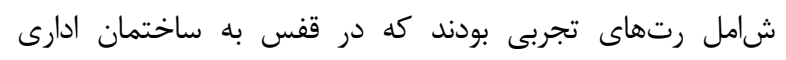

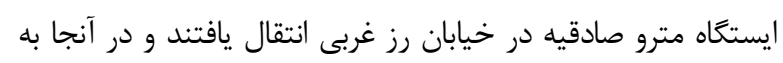

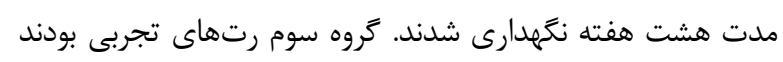

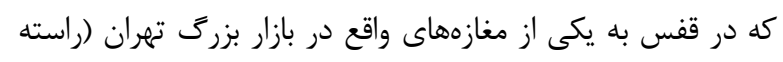

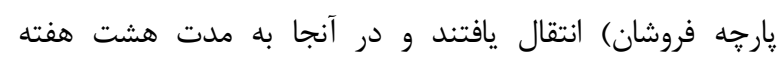

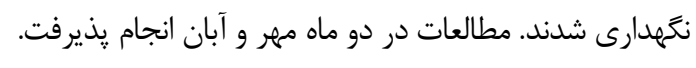

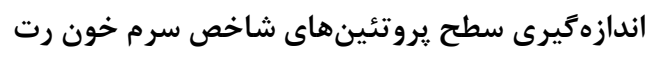

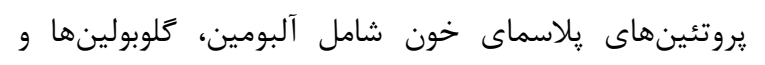

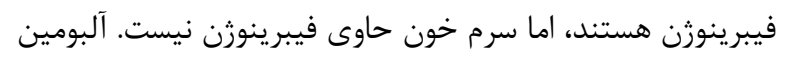

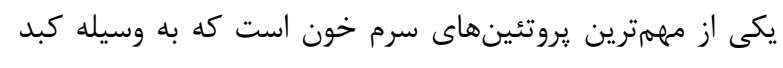

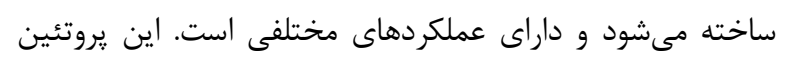

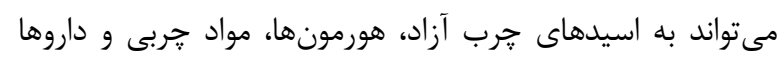

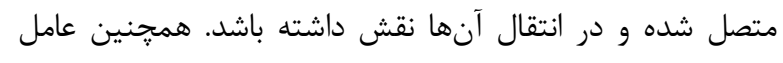
اصلى ايجادكننده فشار اسمزى خون، يروتئين آلبومين است.

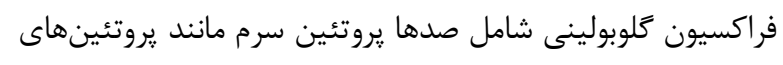

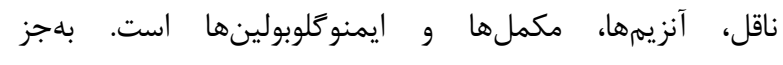

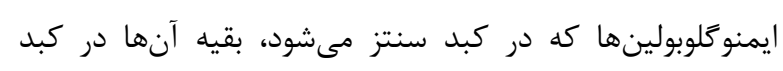

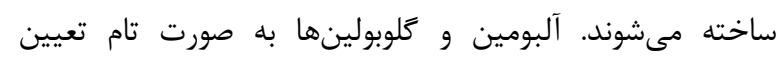

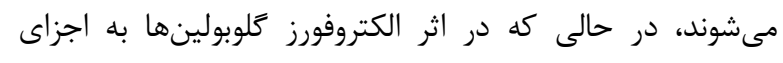

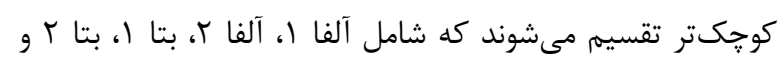

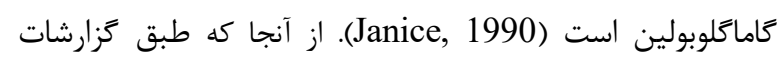

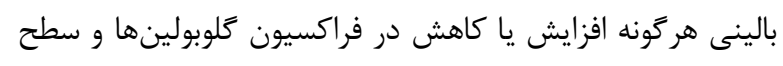
آلبومين خون از لحاظ بالينى بسيار حائز اهميت است، لذائ لذا اين

تغييرات توسط الكوى الكتروفورز سرم خون ارزيابى مى خرددد.

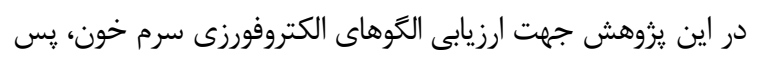

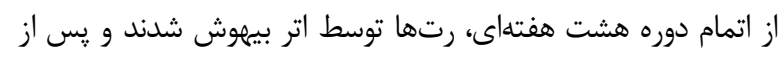
استريل كردن قسمت شكمى، برش طولى روى آنها ايجاد شد.
مطالعات بسيارى در زمينه تاثير صوت بر باردارى، آنزيمها و سطح استرس و هورمونها در شرايط in vivo صورت ترفتئه

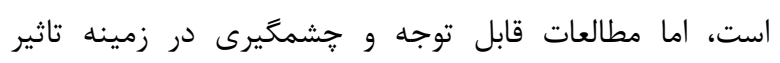

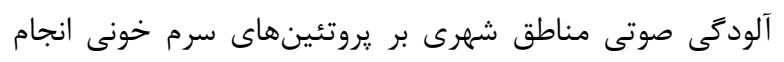

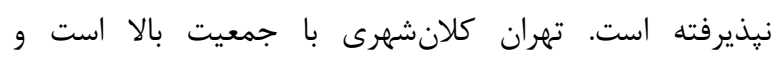

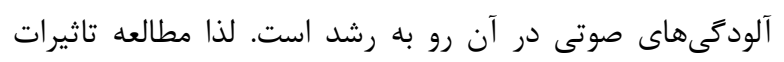

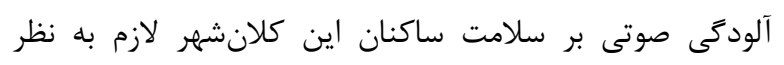

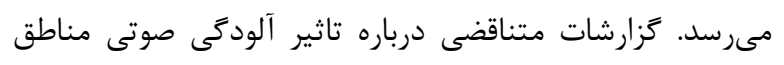

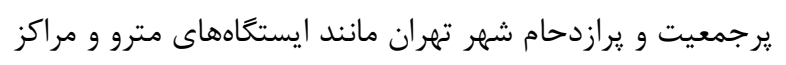

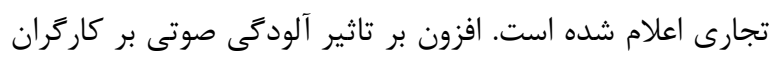

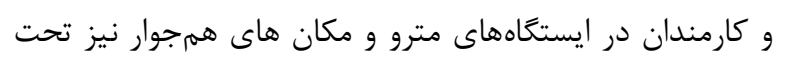

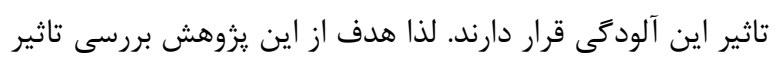

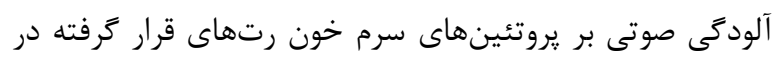

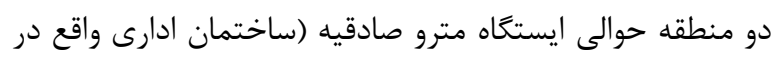

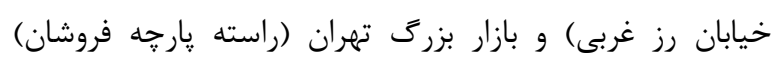

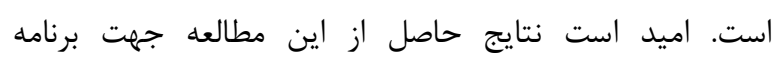
ريزىهاى موثر در كاهش آلودگى صوتى شهرى مفيد واقع شود.

$$
\text { مواد و روش هات }
$$

حيوانات

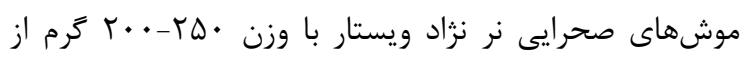

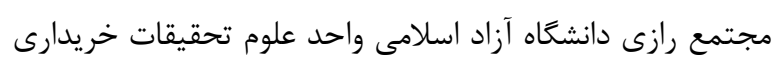

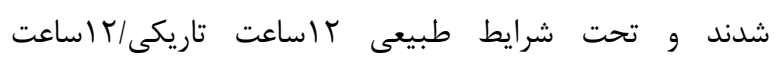

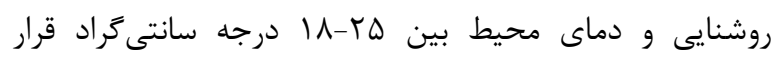

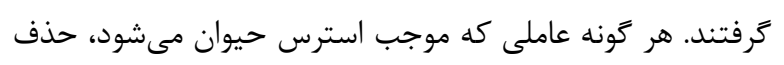

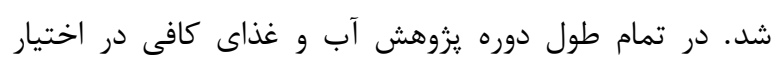

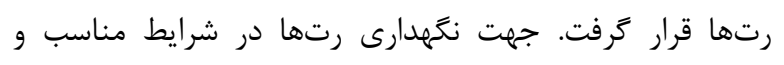

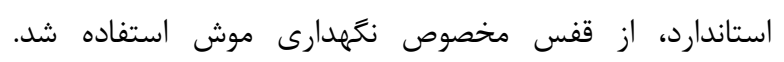

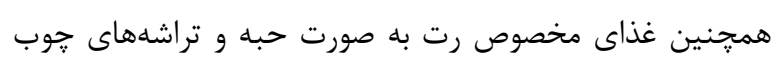

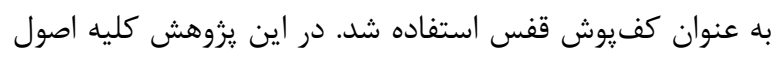

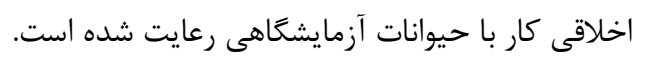
مكان مطالعه ايستخاه مترو صادقيه تهران داراى دو ورودى شمالى (از سمت

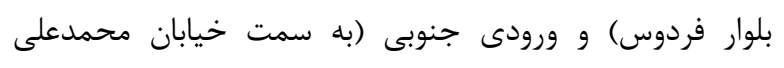

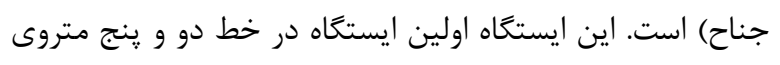

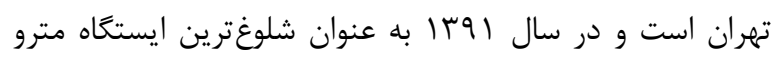

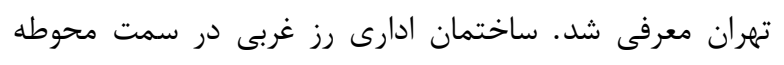

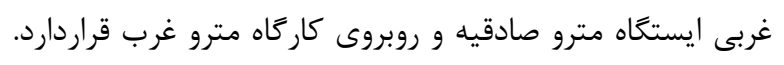

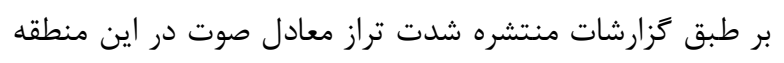

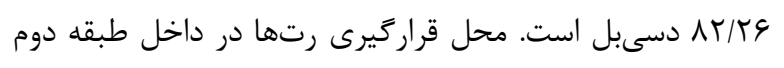



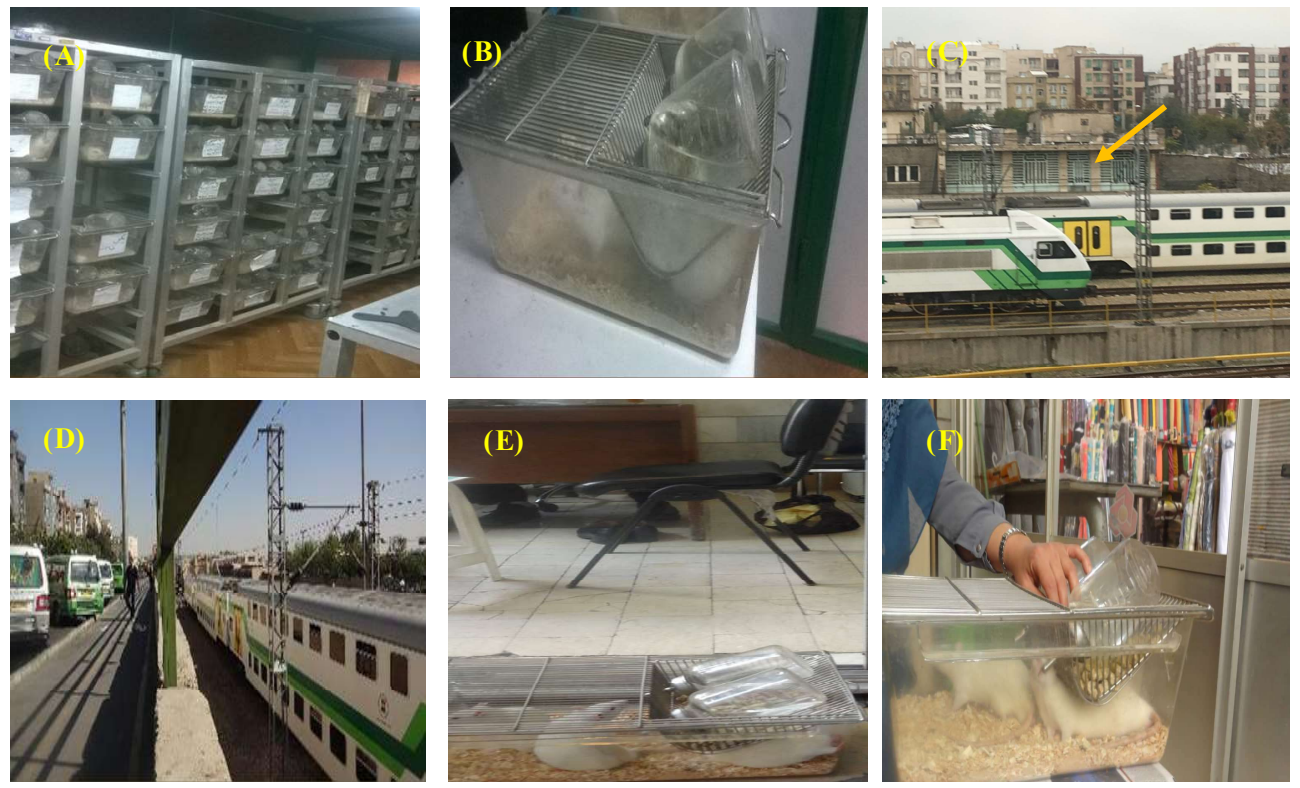

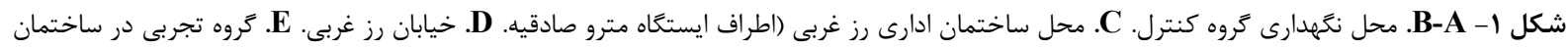

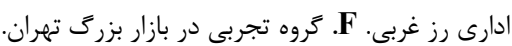

Fig. 1. A-B. Control groups. C. West Rose office building location (in the vicinity of Sadeghiyeh metro-station). D. West Rose Street. E. Experimental groups located in West Rose building. F. Experimental groups located in the Tehran Grand Bazaar.

اصلى سرم يعنى آلبومين، آلفا كلوبولين، آلفا ب حلوبولين،

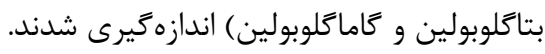
مطالعات جذب مرئى -فرابنفش روشهاى طيفسنجى از مهممترين روش هاى مطالعه ساختمان

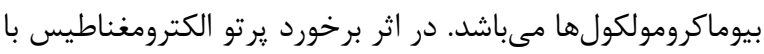
ماكرومولكولهاى حياتى مىتوان اطلاعات ساختارى و عملكردى آنها را به دست آورد. طيفسنجى جذبى مرئى-فرابنفش يك مئى روش اساسى جهت بررسى تغييرات ساختارى يروتئينها است.

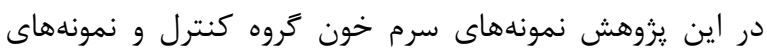
سرم خون گروههاى تجربى كه به مدت هشت هفته در معرض آلودگى صوتى قرار گرفته بودند در دستخاه طيفسنجى درنى مرئى فرابنفش (spectrophotometer, 100 UV-Visible, Cary) در دماى V I درجه سانتى

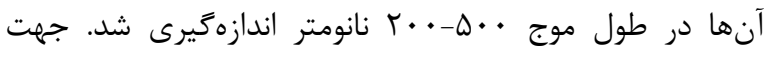

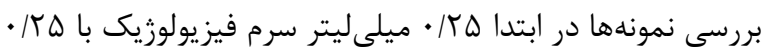

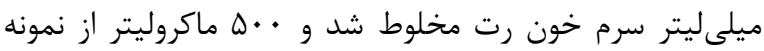
مربوطه در دستخاه طيفسنجى مرئى-فرابنفش قرار گرفت و و

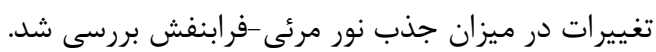

$$
\text { تحليل كمومتريكس }
$$

كمومتريكس (شيمى سنجى) از آمار، جبر خطى و كامييوتر براى آناليز دادهاى شيميايى و بيوشيميايى استفاده مى كند و
بِ از جدا كردن يوست اين ناحيه و سيس يرده ديافراتم، جناق

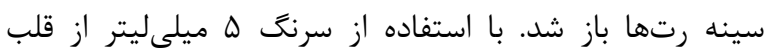
خونكيرى شد. سيس سرم خونى توسط سانتريفيوز با . .. دم دور

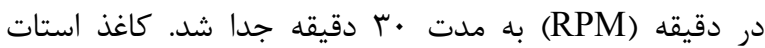

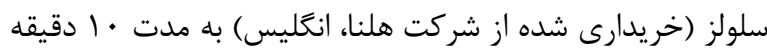
داخل بافر باربيتال شامل باربيتوريك اسيد و سديم قرار كرفتر سرئ. سيس كاغذ استات سلولز بين دو صفحه كاغذ صافى نمزيرى برى

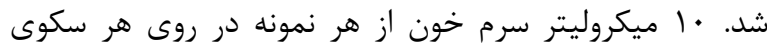

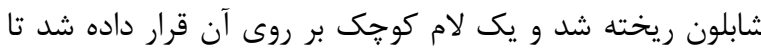
بخار نشود. سيس توسط إيليكاتور نمونهگيرى انجام شد (براى نمونه كذارى نوك ايليكاتور ه ثانيه با كاغذ استات تماس داشت).

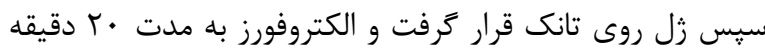
در ولتاز • \1 ميلىولت و جريان بين V-ه ميلى آمير انجام شد. يس از اتمام زمان الكتروفورز، زل به مدت ل- له دقيقه داخل

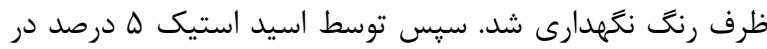

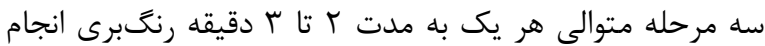

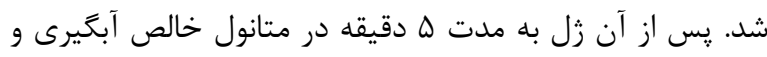

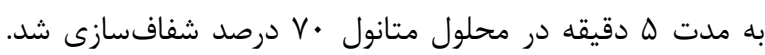

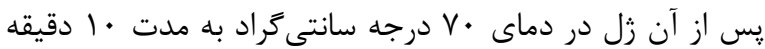

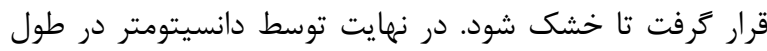

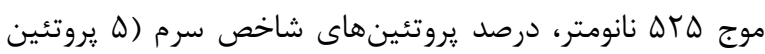


قيدهاى متعددى اعمال مىشود تا منفى نبودن، يونى مودال

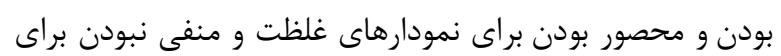

نمودارهاى طيف گونهها اعمال شود (Pirzadeh et al., 2006).

\section{نتايج}

اندازهكيرى سطح بروتئينهاى شاخص سرم خون

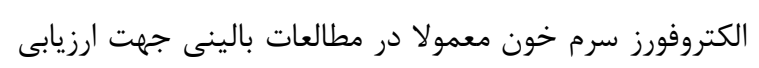

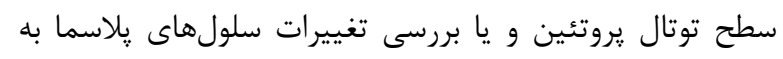

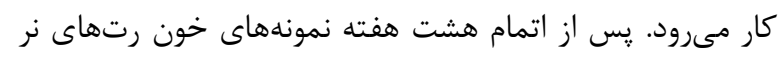

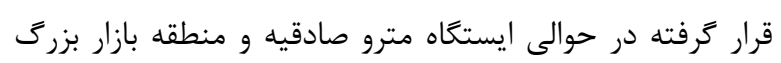

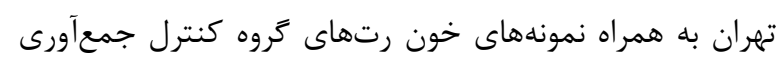

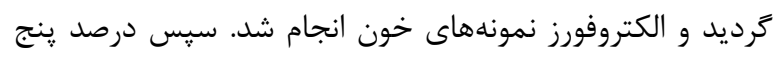

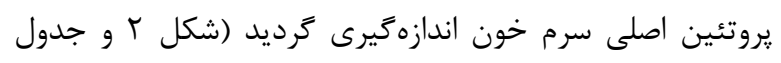

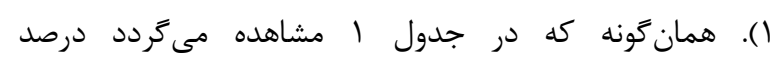

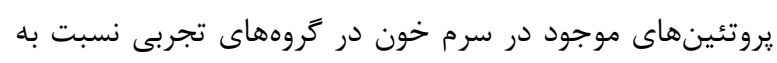
كروه كنترل تغييرات معنى دار (

\section{مطالعات طيف سنجى مرئى -فرابنفش سرم خون}

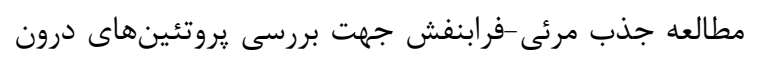

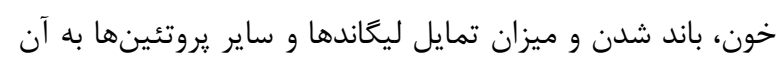

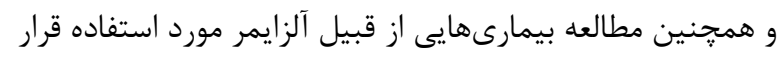
مى نانومتر در طيف جذبى فرابنفش مربوط به جذب رجب زروههاى

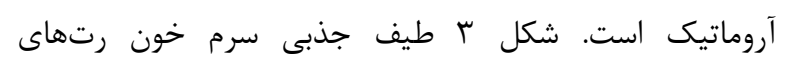

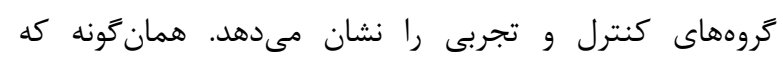

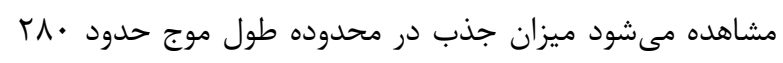

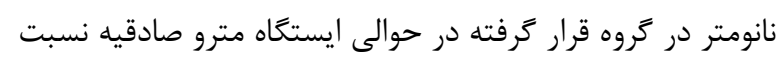

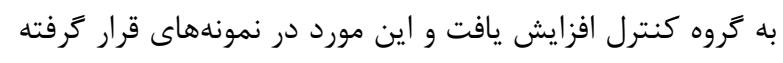

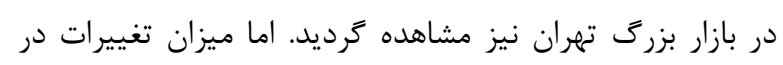

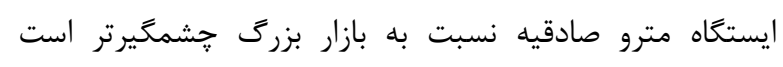

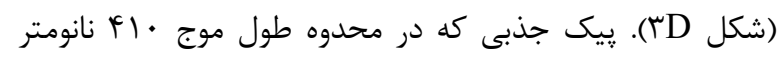

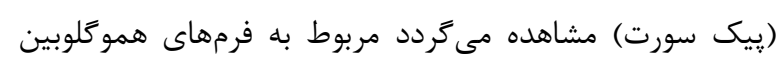

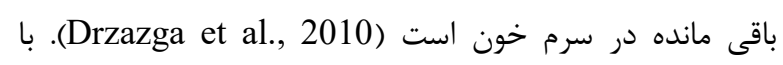

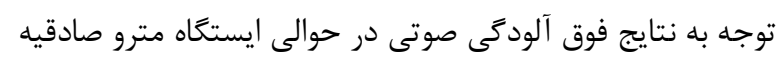

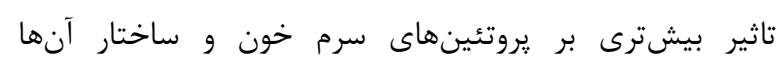

$$
\text { مى مَذارد. }
$$

\section{مطالعات كمومتر يكس}

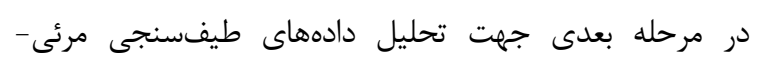

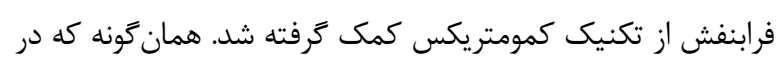

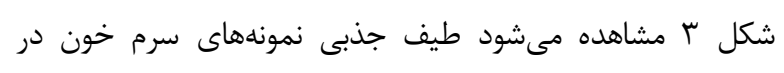

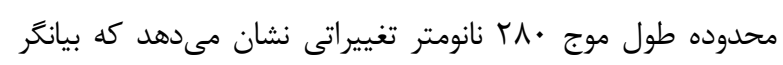

هدف آن استخراج بيشترين اطلاعات از دادههاى تجربى است.

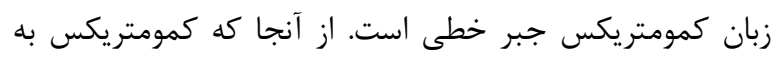

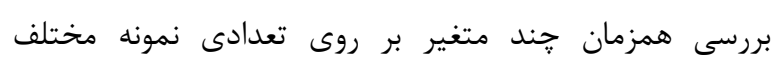

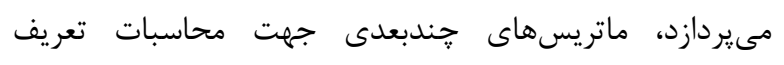

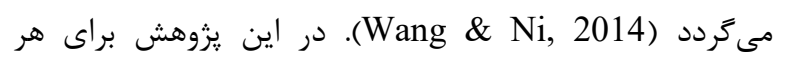

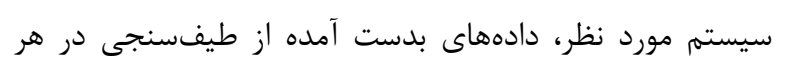

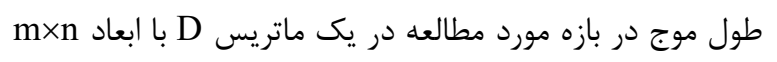

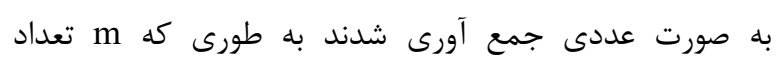

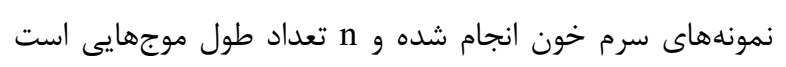

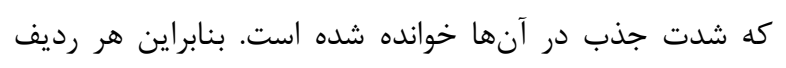

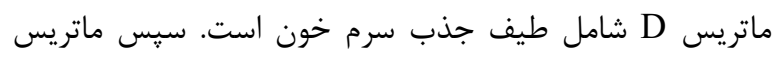

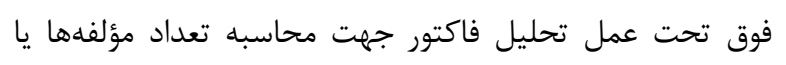

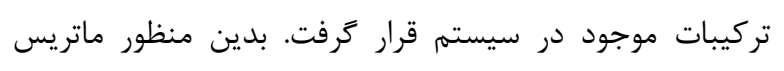

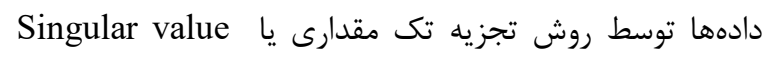

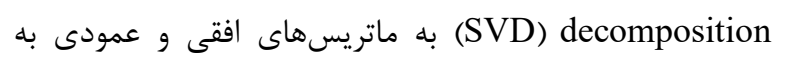

$$
\text { D=TP }
$$
در اين رابطه ماتريسهاى T و P رامل بردارهاى ويزه عمود و

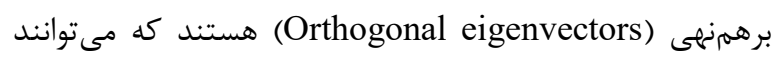
فضاى رديف و ستون دادههاى اصلى را اندازه بحيرند. براى تعيين

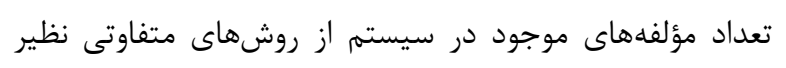

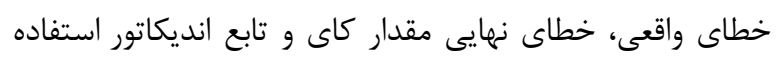

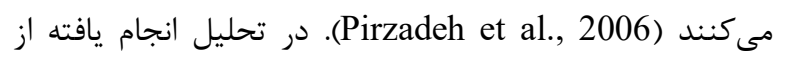
روش MCR-ALS براى حل مؤلفههاى طيفهاى محض و نمودارهاى غلظتهاى مربوط به هر مؤلفه استفاده شد.

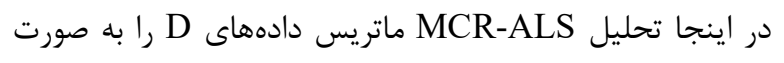

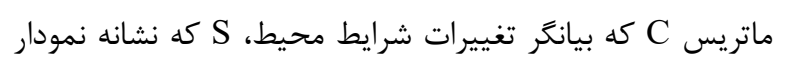

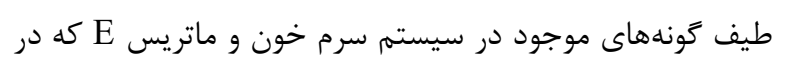
بركيرنده آشوبهاى موجود در سيستم است، تجزيه مى كنيد: در يك فرايند برگشتى ماتريس C و Cبه كَنهاى محاسبه شد تا

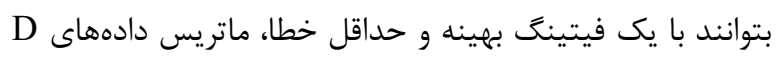

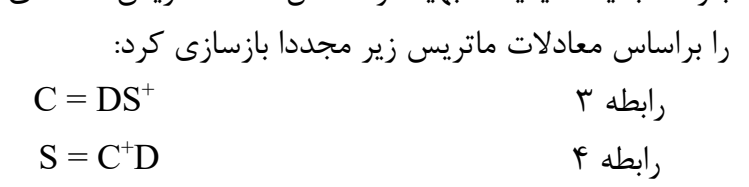
انديس (+) نشانه يك ماتريس شبه معكوس است. يك حدس

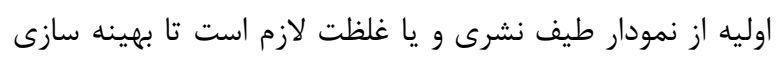
ALS

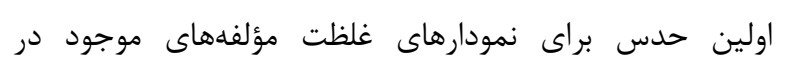

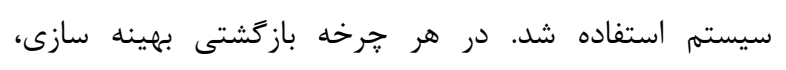


بيش از 11 إسىىل داعه مدت دو هفته و ده ساعت در روز مىتواند باعث كاهش معنى دار سطح هورمونهاى تستوسترون، برولاكتين،

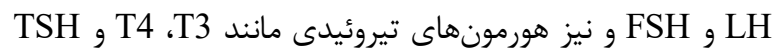
شود (Chamkori et al., 2016). در اين مطالعه به بررسى آلودگى صوتى در دو منطقه بازار بزرى

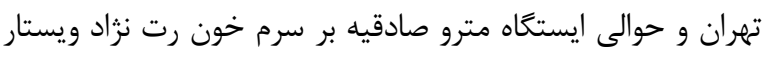

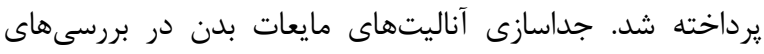

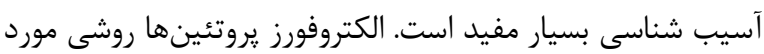

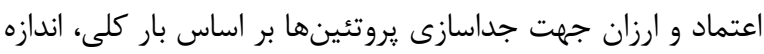

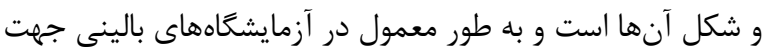
غربالكرى ناهنجارى هاى يروتئين در مايعات بيولوزى (سرم، ادرار و و

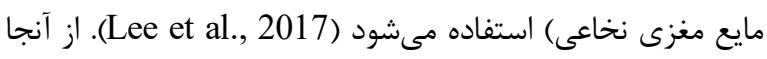

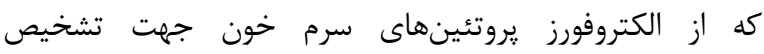

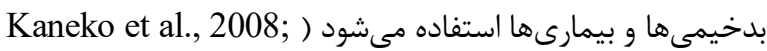
Rasouli et al., 2005 خون مىتواند نتايج قابل قبولى جهت مطالعه تاثير عوامل مختلف شيميايى و محيطى به همراه داشته باشد.

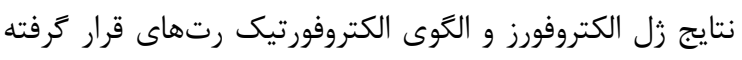

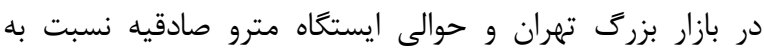
نمونههاى كنترل تغييراتى را نشان داد. در منطقه ايستخاه مترو

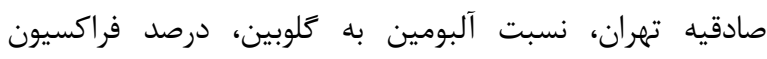
آلبومين، درصد فراكسيون آلفا ا كَلوبولين و درصد فراكسيون آلفا r كلوبولين نسبت به نمونههاى كنترل كاهش مرصد معنادارى را را نشان

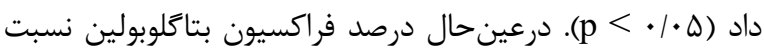

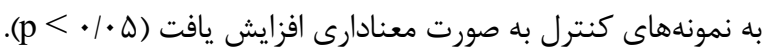
اين در حالى است كه در ميزان بروتئين كاماتلوبولين تغييرى معنادار مشاهده نشد. كاهش فراكسيون آلبومين و فراكسيون درين آلفان

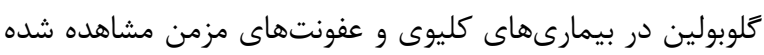

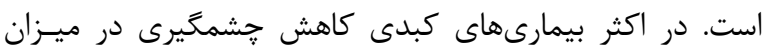

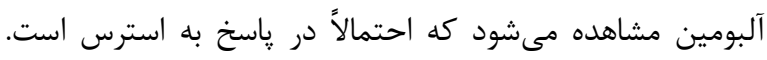

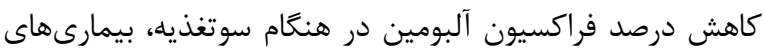
كبدى و افزايش رقت خون مشاهده شده است ( Lee et al.,

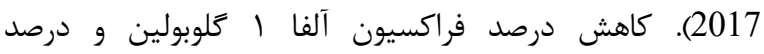

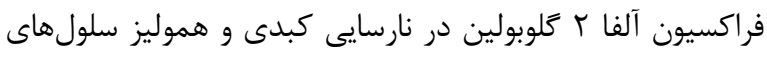

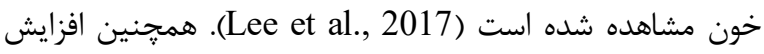
درصد فراكسيون بتاكلوبولين در بيمارىهاى عفونى، كاهش ميزان إندان

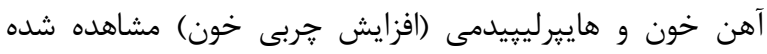

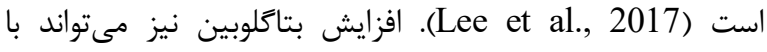
بيمارىهاى كليوى در ارتباط باشد (Kyle et al., 2002).
تغيير در گروههاى آروماتيك يروتئينهاى سرم خون است. ميزان

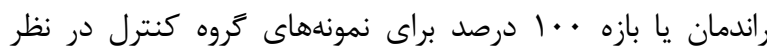

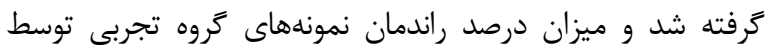

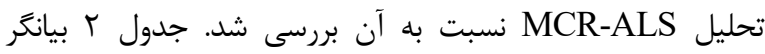

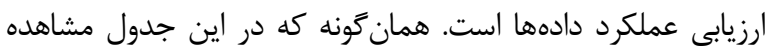

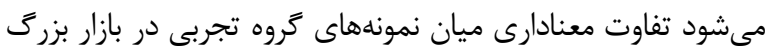

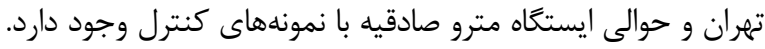

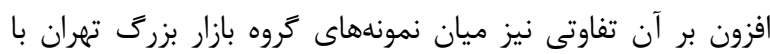

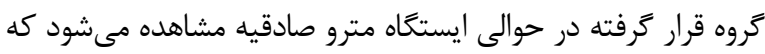

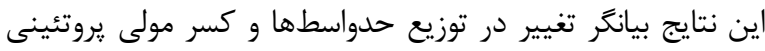

سرم خون است (Pirzadeh et al., 2006).

بحث

آلودگى صوتى يكى از شايعترين عوامل زيانآور فيزيكى در

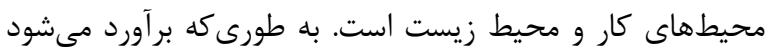

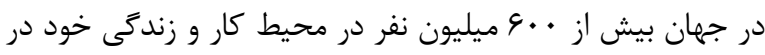

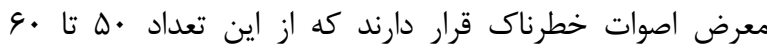

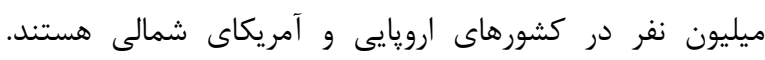

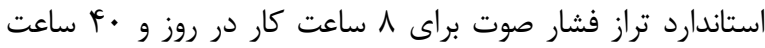

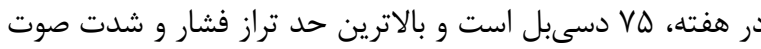

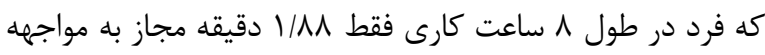

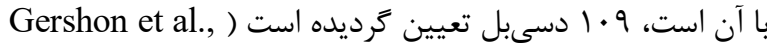

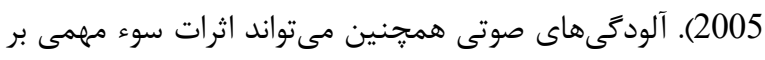

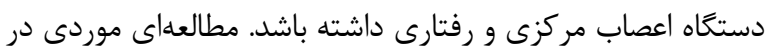

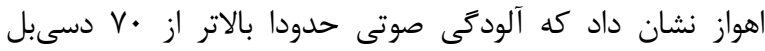

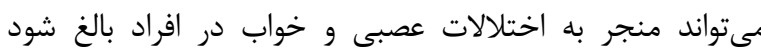

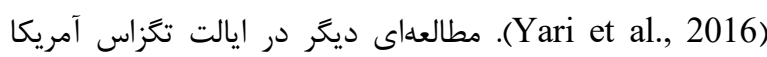

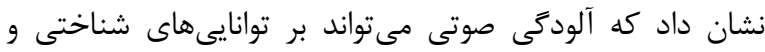

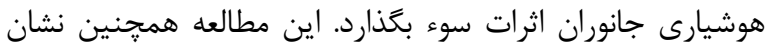

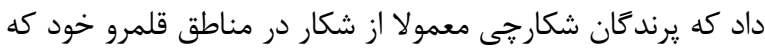

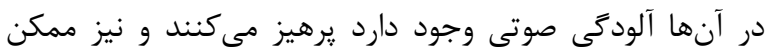

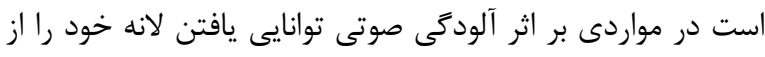

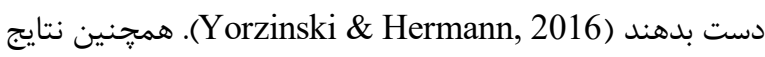

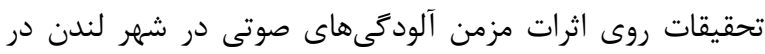

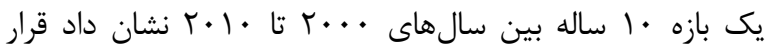

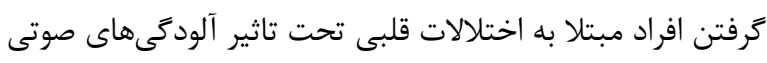
به شكل مستمر مىتواند با افزايش خطر سكته قلبى و كاهش طول

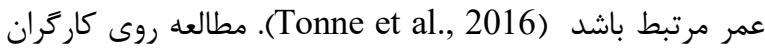
صنعتى بوشهرى نشان داد كه قراركيرى در معرض آلودگى صوتى (T). مطالى 

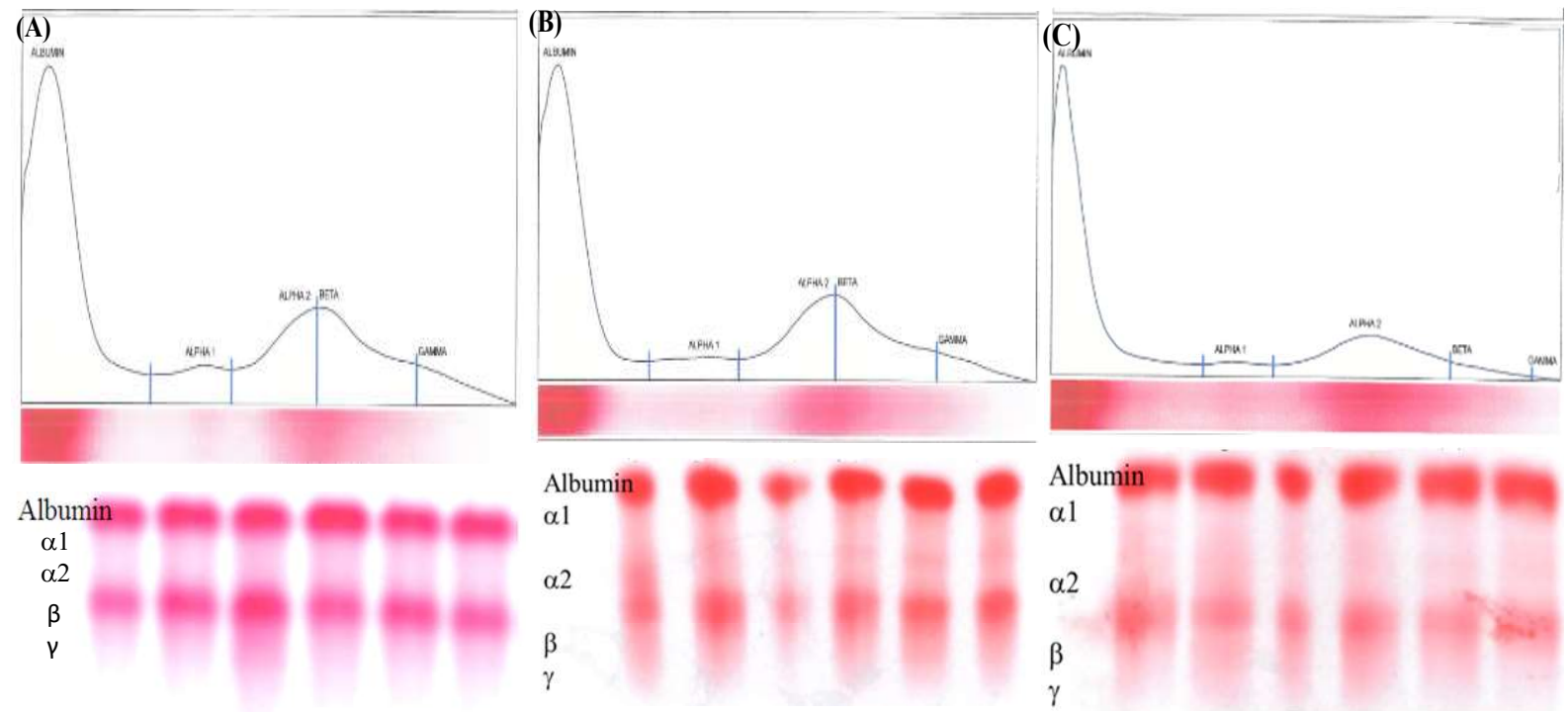

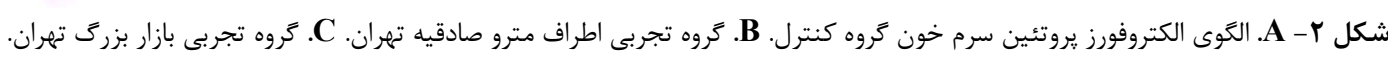
Fig. 2. A. The electrophoresis pattern of serum proteins of control group. B. The experimental group located in the vicinity of Sadeghiyeh metro-station. C. The experimental group located in Tehran Grand Bazaar.

جدول ا- ميانكَين و تفاوت در غلظت يروتئين توتال، درصد فراكسيونهاى يروتئين و نسبت آلبومين/گلوبين (A/G) حاصل از الكتروفورز سرم خونى كروههاى تجربى و كروه كنترل.

Table 1. Average values and significance of differences for the total protein concentration, the percentage of protein fractions, and the albumin/globulin $(\mathrm{A} / \mathrm{G})$ ratio obtained by electrophoresis of blood serum from experimental and control groups.

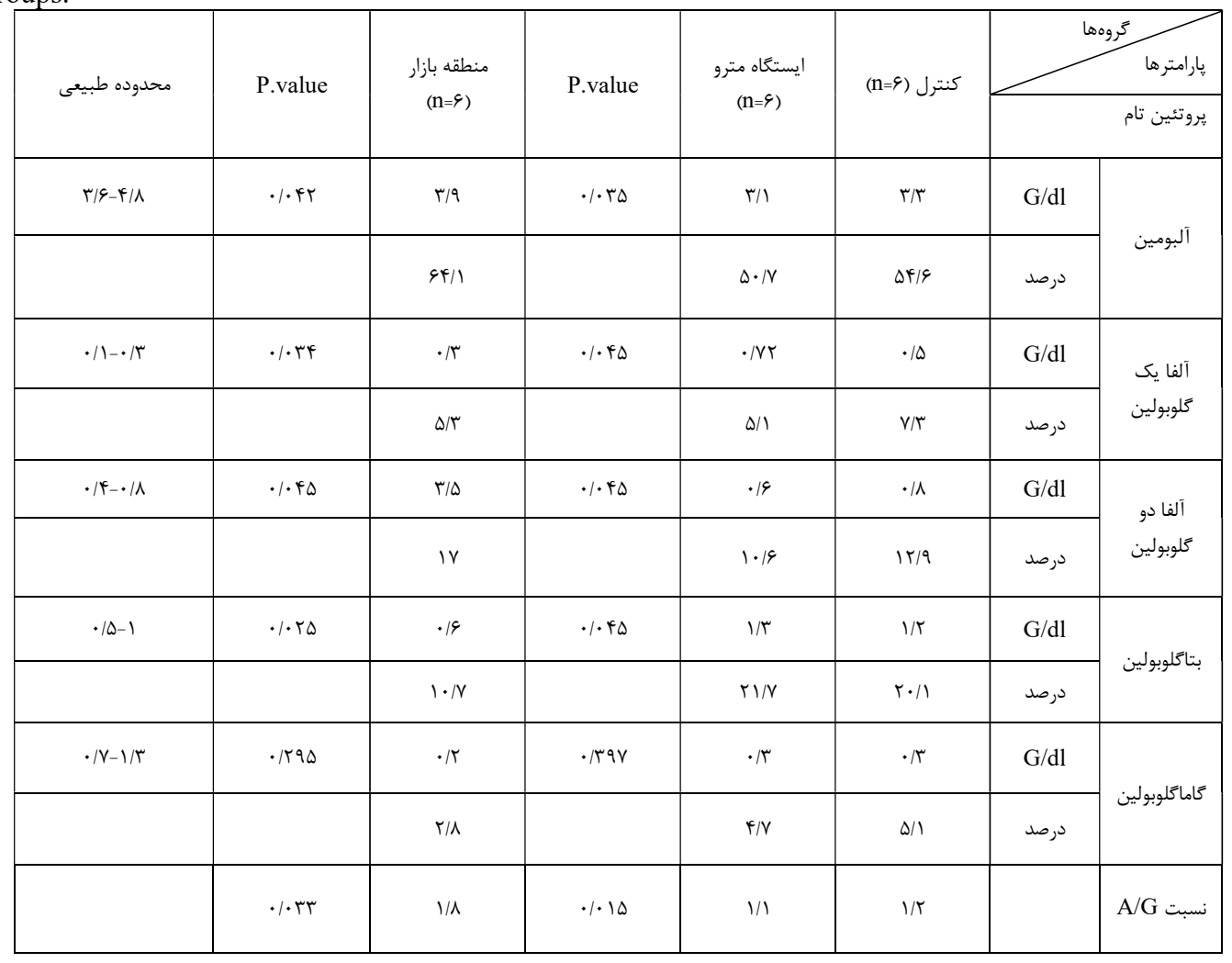



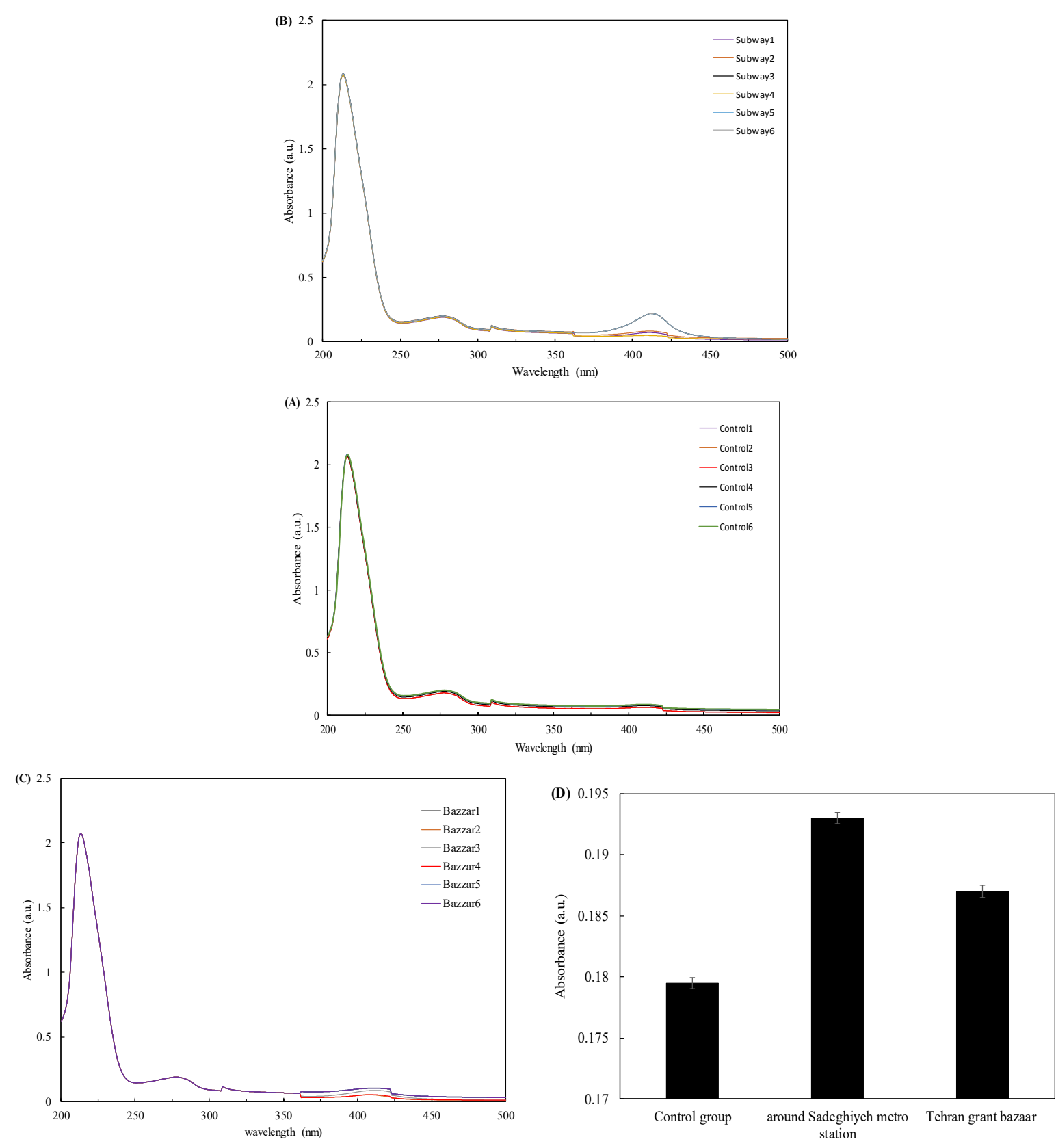

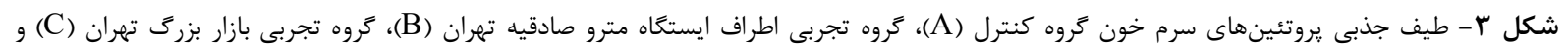

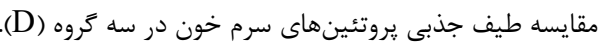

Fig. 3. Absorbance spectra of blood serum proteins of control group (A), the experimental group located in the vicinity of Sadeghiyeh metro station (B), the experimental group located in Tehran Grand Bazaar (C) and the comparison of absorption spectrum of serum proteins in three groups (D).

$$
\text { جدول r- ميانگين ارزيابى عملكرد (برحسب درصد) نمونهاى سرم خون گروههاى تجربى و گروه كنترل }
$$

\begin{tabular}{|c|c|}
\hline ارزيابى عملكرد (\%) & نمونه \\
\hline $1 \cdots$ & تروه كنترل \\
\hline $91 / \cdot \cdot$ & گروه تجربى ايستخاه مترو صادقيه \\
\hline$V T / \Delta \Delta$ & گروه تجربى بازار بزرى تهران \\
\hline
\end{tabular}

Table 2. The percentage of the performance of experimental and control blood serum groups. 
آلودگى صوتى مشاهده گرديد. به عبارت ديخر آلودگى صوتى

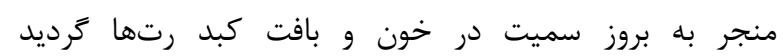

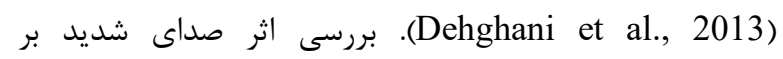

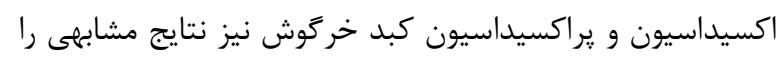

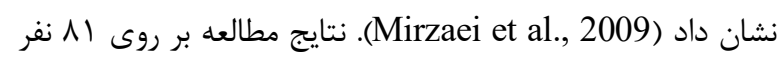

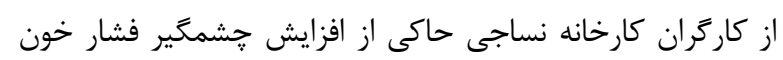

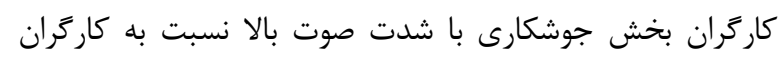
بخشهاى ديخر با شدت صوت كمتر بود (Nasiri et al., 2003).

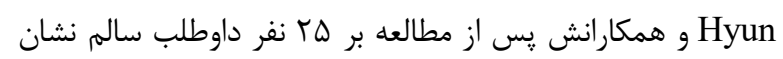

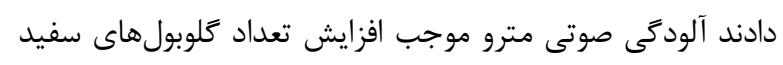

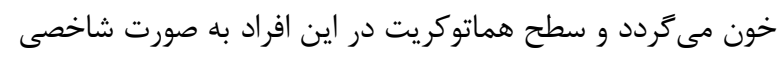

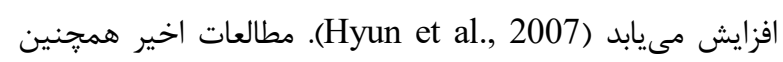

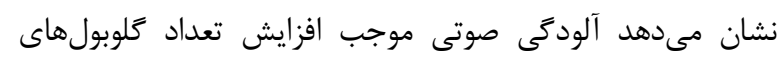

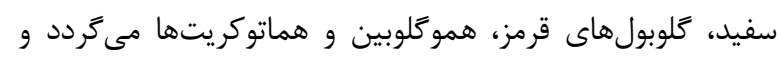

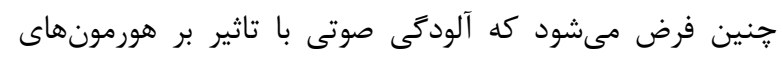

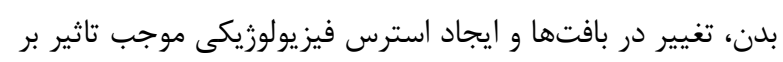

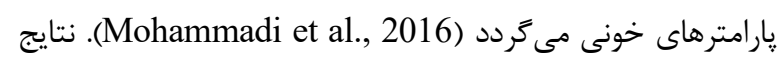

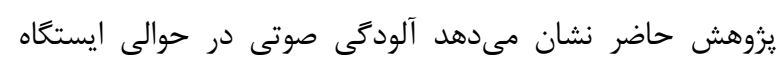

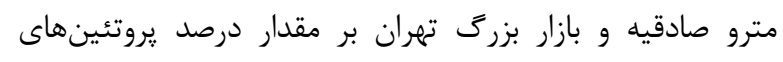

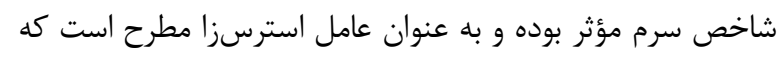

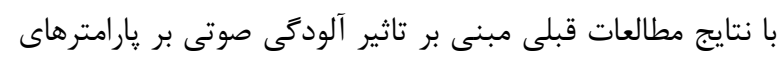
فيز يولوزيك خون مطابق است.

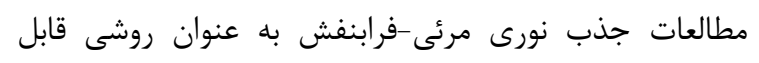

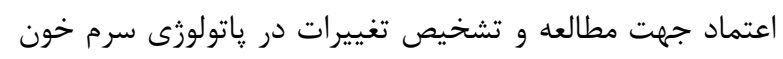

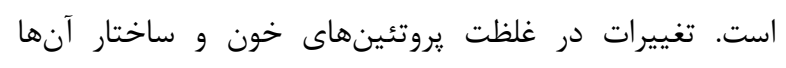
موجب بروز بيمارىهايى از قبيل سرطان و آلزايمر مىشون

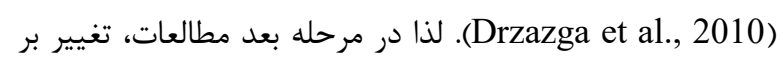
ميزان جذب نور مرئى-فرابنفش سرم خون رتهاى قرار كرفته در

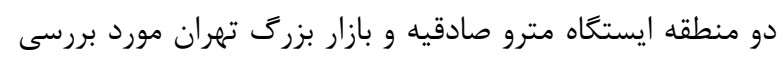

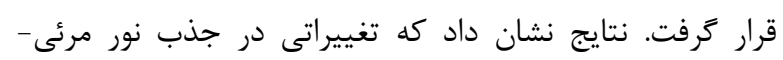

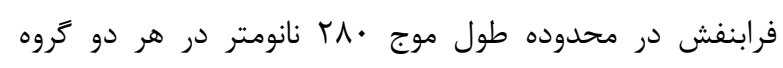

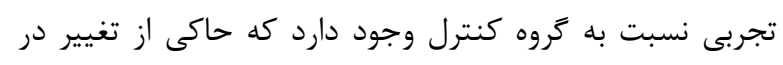

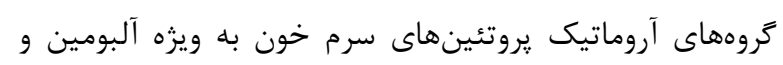

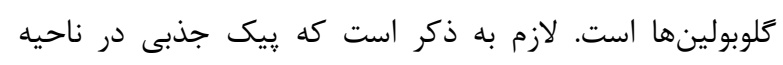

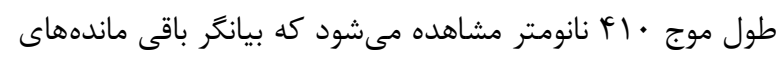

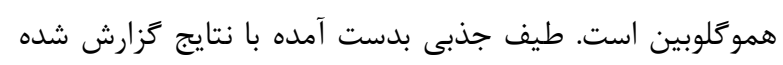

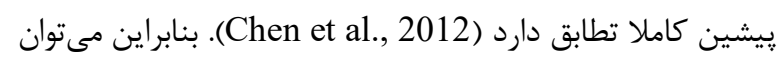

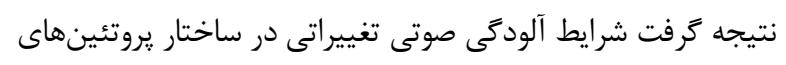

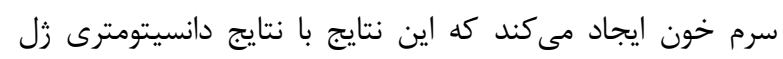

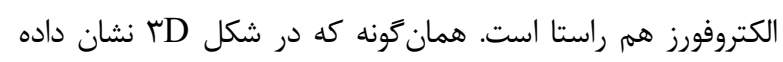

در منطقه بازار بزرى تهران نسبت آلبومين به كلوبين، درصد

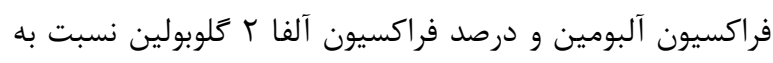

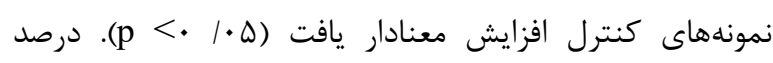

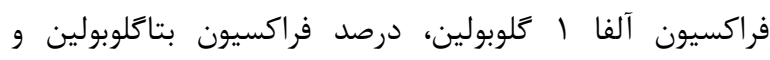

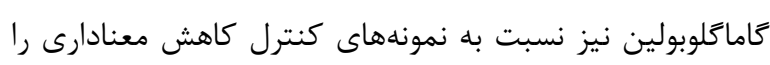

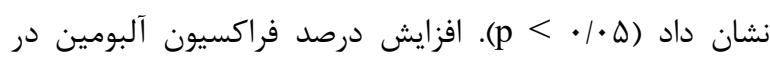

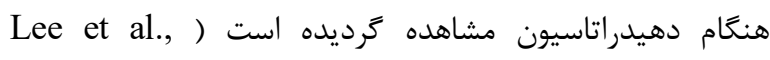

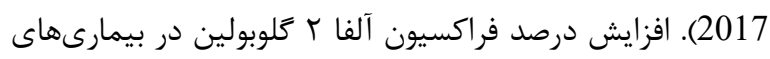

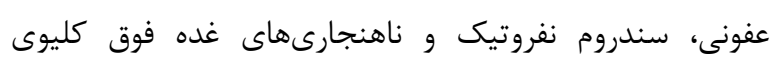

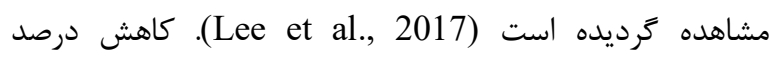

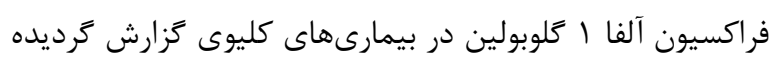

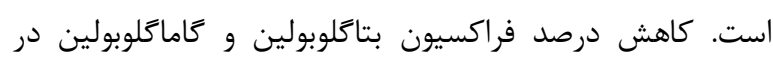
بيمارىهاى عفونى مشاهده شده است (Lee et al., 2017).

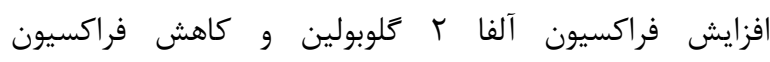

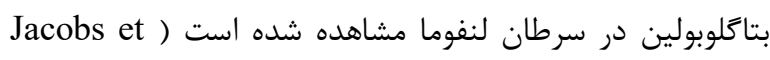
دان در سرطان هاجكين مشاهده شده است (Gobbi et al., 1985).

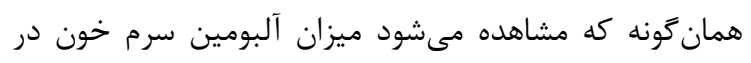

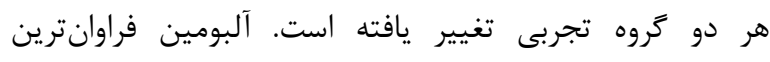
يروتئين موجود در سرم خون است و دو سوم سوم كل يروتئين تئهاى

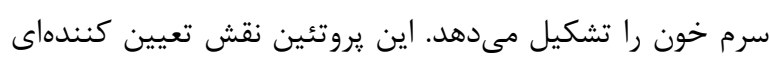

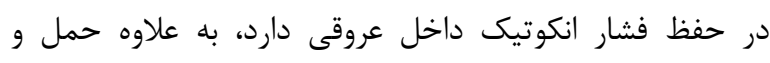

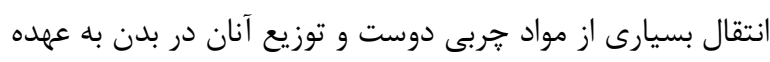

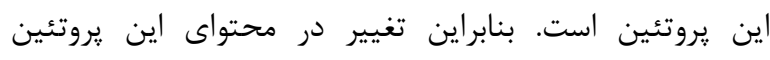

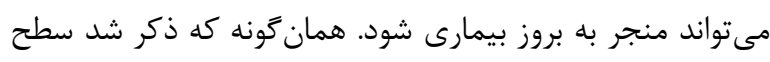

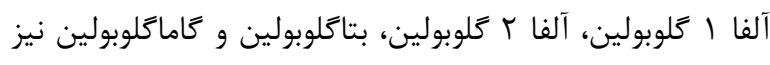

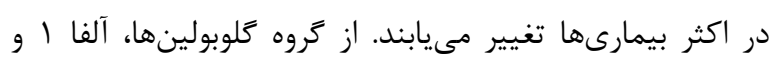

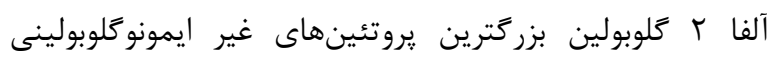

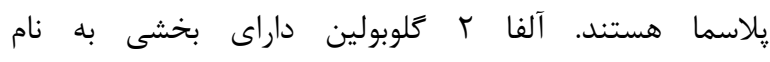

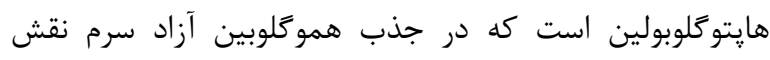

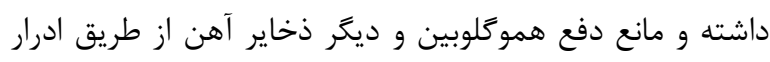

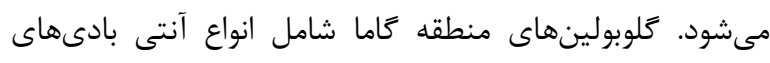

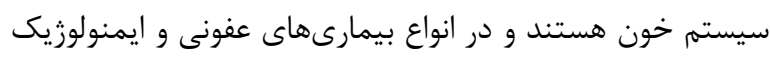

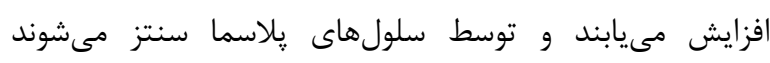

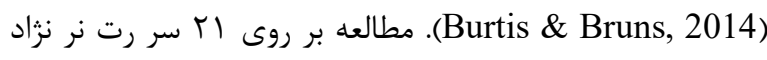
ويستار قراركرفته در معرض آلودگى صوتى با تراز شدت مات بالا،

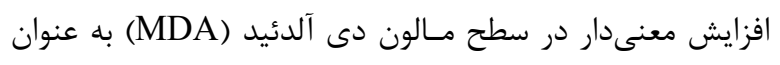

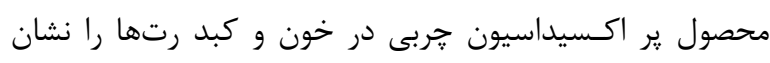

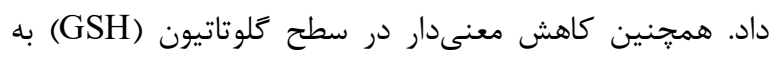

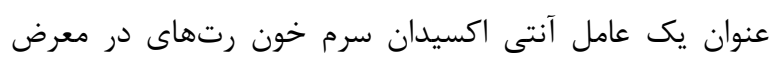


(ساختمان ادارى واقع در خيابان رز غربى) و منطقه بازار بزرى

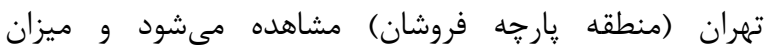

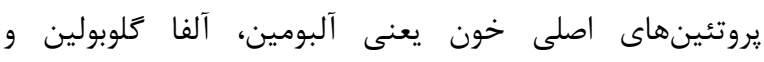

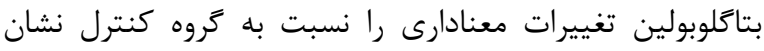

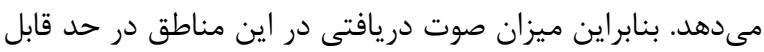

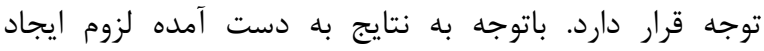

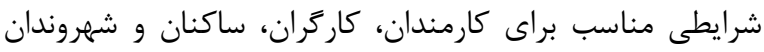

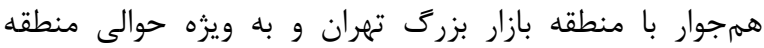

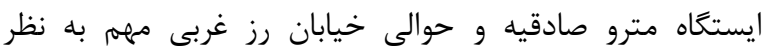

\section{سياسگزارى}

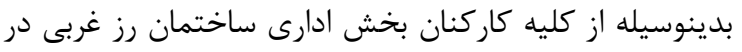

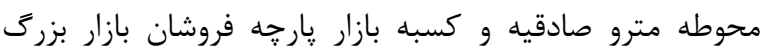

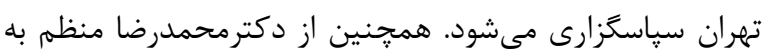
جهت رهنمودهاى ارزشمندشان قدردانى مى مئرد.

\section{REFERENCES}

Burtis, C.A. \& Bruns, D.E. 2014. Tietz fundamentals of clinical chemistry and molecular diagnostics (Fundamentals of Clinical Chemistry (Tietz)). Saunders. 7th Edition. pp: 1-1104.

Chamkori, A., Shariati, M., Moshtaghi, D. \& Farzadinia, P. 2016. Effect of noise pollution on the hormonal and semen analysis parameters in industrial workers of Bushehr, Iran. Crescent J. Med. Biol. Sci. 3: $45-50$

Chen, P., Zhang, L., Zhang, F., Liu, J.T., Bai, H., Tang, G.Q. \& Lin, L. 2012. Spectral discrimination between normal and leukemic human sera using delayed luminescence. Biomed. Opt. Express. 3: 1787-1792.

Dehghani, A., Ranjbarian, M., Khavanin, A., Rezazade, A.M. \& Vosooghi, S. 2013. Exposure to noise pollution and its effect on oxidant and antioxidant parameters in blood and liver tissue of rat. Zahedan J. Res. Med. Sci. 15: 13-17.

Drzazga, Z., Michalik, K., Halat, T., Michnik, A. \& Trzeciak, H. 2010. Calorimetric and spectroscopic studies characterization of newborn rat'blood serum after maternal administration of cyclophosphamide. J. Therm. Anal. Calorim. 102: 143-148.

Gershon, R.R., Qureshi, K., Barrera, M., Erwin, M. \& Goldsmith, F. 2005. Health and safety hazards associated with subways: a review. J. Urban Health 82: 10-20.

Gobbi, P.G., Gendarini, A., Crema, A., Cavalli, C., Attardo-Parrinello, G., Federico, M. \& Ascari, E. 1985. Serum albumin in Hodgkin's disease. Cancer. 55: 389-393.

Hamidi, M., Kavousi, A., Nasiri, P., Hamedani, A., Kiani, S. \& Dehghan, H.R. 2012. Study of noise pollution in urban and the suburbs railway. J. Occup. Health 9: 76-82.
شده است ميانگين تغييرات در محدوده طول موج • † نانومتر در نمونههاى تجربى قرار گَرفته در حوالى ايستخاه مترو صادقيه

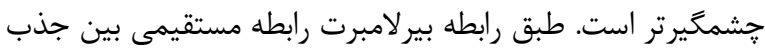

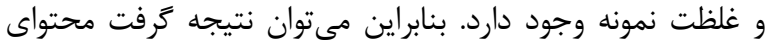

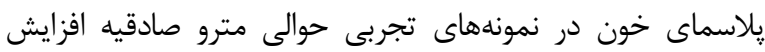

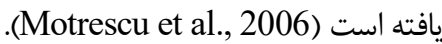
دادهاي طيفسنجى -مرئى فرابنفش مىتواند به عنوان دادهاى خام براى مطالعات كمومتريكس مورد استفاده قرار كيرد. روشهاى آناليز كمومتريكس متنوع هستند. از ميان روشهاى جندمتغيره مورد استفاده در كمومتريكس روش روش

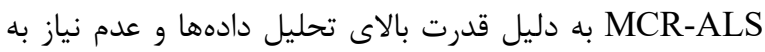
دانش بالاى آمار و رياضيات بيشتر مورد استقبال يزوهشگران

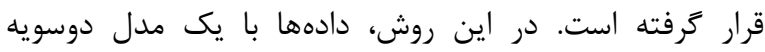

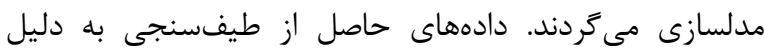
تبعيت از قانون بير لامبرت ساختارى دوسويه دارند، بنابراين روش

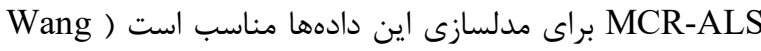
جمن Ni, 2014 جهت شناسايى متابوليتهاى خون، شناسايى هماتوكريتها و

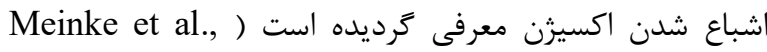
2005; Trygg et al., 2007 جCR-ALS

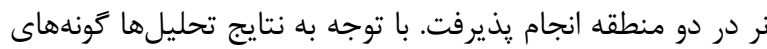
موجود در منطقه بازار بزرگ تهران و حوالى ايستخاه مترو صادقيه تغييرات معنادارى نسبت به گروه كنترل نشان داد. قابل توجه آنكه دو گونه موجود در بازار بزرى تهران و حوالى ايستعاه مترو صادقيه

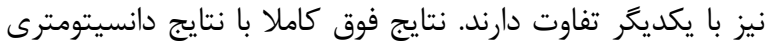
سرم خون تطابق دارد و به نظر مىرسد هر دو منطقه موجب تغييراتى در يروتئينهاى سرم خون ميش شوند كه البته اين مكانيزم اين تغييرات در دو منطقه با يكديكر متفاوت است. با توجه به مطالعات به نظر مىرسد آلودگى صوتى در حوالى ايستگاه مترو صادقيه (ساختمان رز غربى) تاثير بيشترى بر ميزان سرم خون رتهاى مورد آزمايش نسبت به منطقه بازار بزرى تهران دارد. لازم

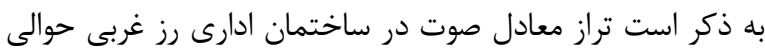

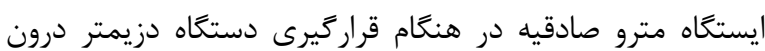
اتاق در بسته اندازهگيرى شد و اين دادهها مربوط به محوطه خارج از ساختمان و ساختمانهاى اطراف نيست.

$$
\text { نتيجه }
$$

با توجه به نتايج حاضر، تغييرات در سطح يروتئين سرم خون رتهاى قرار گرفته در دو منطقه حوالى ايستخاه مترو صادقيه 
Hamidi, M., Kavousi, A., Zaheri, S., Hamadani, A. and Mirkazemi, R. 2014. Assessment of the noise annoyance among subway train conductors in Tehran, Iran. Noise Health 16: 177-182.

Hassani, F., Nasiri, P. \& Monnazam, M. 2017. Study of noise pollution in workshops and noise making jobs in Zone 3 of District 12 of Tehran (Bazar Bozorg) using GIS. J .Env. Sci. Tech. 19: 1-11.

Hyun, K.Y., Kim, C.R. \& Choi, S.C. 2007. Physiological Influence of combined mental activity with experimental subway noise. J. Exp. Biomed. Sci. 13: 39-45.

Jacobs, R., Valli, V. \& Wilkie, B. 1980. Serum electrophoresis and immunoglobulin concentrations in cows with lymphoma. Am. J. Vet. Res. 41: 1942-1946.

Janice, T.B. 1990. Clinical Methods; The history, physical and laboratory examination. 3rd Edition. Boston, Butterworths. pp: 477-499.

Kaneko, J., Harvey, J.W. \& Bruss, M.L. 2008. Clinical biochemistry of domestic animals. Academic press. 1-916.

Kyle, R., Katzmann, J., Lust, J. \& Dispenzieri, A. 2002. Clinical indications and applications of electrophoresis and immunofixation. Manual of Clinical Immunology, Sixth Edition. pp: 66-67.

Lee, A.Y., Cassar, P.M., Johnston, A.M. \& Adelstein, S. 2017. Clinical use and interpretation of serum protein electrophoresis and adjunct assays. Br. J. Hosp. Med. 78: C18-C20.

Meinke, M., Gersonde, I., Friebel, M., Helfmann, J. \& Müller, G. 2005. Chemometric determination of blood parameters using visible-near-infrared spectra. Appl. Spectrosc. 59: 826-835.

Mirzaei, R., Alameh, A., Mortazavi, S., Khavanin, A. \& Kamalian, N. 2009. Effects of loud noise on oxidation and lipid peroxidation variations of liver tissue of rabbit. Zahedan. J. Res. Med. Sci. 11:11-17.

Mohammadi, H., Alimohammadi, I., Roshani, S., Pakzad, R., Abdollahi, M.B. \& Dehghan, S.F. 2016. The effect of occupational noise exposure on blood and biochemical parameters: a case study of an insulator manufacturer in Iran. Electron Physician 8: 1740-1746.

Motrescu, I., Oancea, S., Rapa, A. \& Airinei, A. 2006. Spectrophotometric analysis of the blood plasma for different mammals. Romanian J. Biophys. 16: 215-220.

Nasiri, P., Abasi, A., Shataheri, S. \& Pour najaf, A. 2003. Possible impacts of sound total scale on the workers, blood pressure at Zarjeen baft factory in Ilam. J. Ilam Univ. Med. Sci. 11: 23-27.
Pirzadeh, P., Moosavi-Movahedi, A.A., Hemmateenejad, B., Ahmad, F., Shamsipur, M. \& Saboury, A. 2006. Chemometric studies of lysozyme upon interaction with sodium dodecyl sulfate and $\beta$-cyclodextrin. Colloids Surf. B. 52: 31-38.

Pramanik, P. \& Biswas, S. 2012. Traffic noise: a silent killer of male gamete of albino rats. Al Ameen J. Med. Sci. 5: 82-89.

Rabat, A. 2007. Extra-auditory effects of noise in laboratory animals: the relationship between noise and sleep. J. Am. Assoc. Lab. Anim. Sci. 46: 35-41.

Rasouli, M., Ôkhoovatian, A. \& Endrami, A. 2005. The pattern of serum proteins electrophoregram in malignancy. J. Mazandaran Univ. Med. Sci. 15: 9-17.

Rewerska, A., Pawelczyk, M., Rajkowska, E., Politanski, P. \& Sliwinska-Kowalska, M. 2013. Evaluating Dmethionine dose to attenuate oxidative stress-mediated hearing loss following overexposure to noise. Eur. Arch Otorhinolaryngol. 270: 1513-1520.

Ristovska, G., Laszlo, H. \& Hansell, A. 2014. Reproductive outcomes associated with noise exposure - a systematic review of the literature. Int. J Environ Res Public Health 11: 7931-7952.

Saki, G., Jalali, M.A., Sarkaki, A.R., Karami, K. \& Ahangarpoor, A. 2016. Effect of supplementation of zinc on fertilization capacity of male rats exposed to noise stress. Int. J. Pharm. Res. Allied Sci. 5: 67-74.

Tonne, C., Halonen, J.I., Beevers, S.D., Dajnak, D., Gulliver, J., Kelly, F.J. \& Anderson, H.R. 2016. Long-term traffic air and noise pollution in relation to mortality and hospital readmission among myocardial infarction survivors. - Int. J. Hyg. Environ. Health 219: $72-78$.

Trygg, J., Holmes, E. \& Lundstedt, T. 2007. Chemometrics in metabonomics. J. Proteome Res. 6: 469-479.

Wang, Y. \& Ni, Y. 2014. Combination of UV-vis spectroscopy and chemometrics to understand protein-nanomaterial conjugate: A case study on human serum albumin and gold nanoparticles. Talanta 119: 320-330.

Yari, A.R., Geravandi, S., Goudarzi, G., Idani, E., Vosoughie, M., Esfarjani, N.M. \& Malihi, R. 2016. Assessment of noise pollution and its effect on residents health in Ahvaz, Iran in 2011. Arch. Hyg. Sci. 5: 56-60.

Yorzinski, J.L. \& Hermann, F.S. 2016. Noise pollution has limited effects on nocturnal vigilance in peahens. Peer J. 4: e2525.

How to cite this article:

Hekmat, A., Fahimi, Z. \& Haeri Rohani, S.A. 2020. The effects of noise pollution on blood serum protein of Wistar male rats. Nova Biologica Reperta 7: 19-29. (In Persian).

حكمت، آ.، فهيمى، ز. و حائرى روحانى، س.ع. 99זا. تاثير آلودگى صوتى بر بروتئينهاى سرم خون رت نر نزاد ويستار. يافتههاى نوين در علوم زيستى V: 